\title{
Six Myths about Digital Skills Training
}

\author{
Brooke B. Schaab and Franklin L. Moses \\ U.S. Army Research Institute
}

\section{Advanced Training Methods Research Unit Franklin L. Moses, Chief}

\section{U.S. Army Research Institute for the Behavioral and Social Sciences 5001 Eisenhower Avenue, Alexandria, Virginia 22333-5600}

July 2001 